\title{
The Effect of Educational Training and Teacher Professional Training in Improving Teacher Professional Competence at SMA Negeri 2 Bantaeng
}

\author{
Andi Sugiati \\ Pancasila Education and Citizenship of the Faculty of Teacher Training and Education. Universitas \\ Muhammadiyah Makassar, Indonesia \\ Corresponding Author: Andi Sugiati,Email: a.sugiati@gmail.com
}

\begin{abstract}
History: Received 04/01/2022 $\mid$ Revised 07/01/2022 | Accepted 20/01/2021 | Published 31/01/2022
Abstract. This study aimed to determine the effect of teacher professional education and training (PLPG) in improving teacher competence. This research is motivated by the lack of teacher competence, so researchers want to examine the effect of educational training and teacher professional training (PLPG) in improving professional competence. The type of research used was quantitative research with data collection techniques using observation, documentation and questionnaires. The data analysis technique used quantitative data analysis techniques. The results showed that the educational training and teacher professional training (PLPG) affected teacher competence, this was seen from the significance value of 0.001 with the t-test value of 1.196 . Based on the established criteria, if the significance is $0.001<0.005$, then $\mathrm{H} 0$ is rejected, which means there is no influence of teacher professional education and training (PLPG) with teacher competence. At the same time, H11 is accepted, indicating that teacher professional education and training (PLPG) influences teacher professional competence.
\end{abstract}

Keywords: Teacher Professional Training, Education and Training (PLPG), Teacher Competence

\begin{abstract}
Abstrak. Penelitian ini dilatarbelakangi masih kurangnya kompetensi guru sehingga peneliti ingin meneliti pengaruh pelatihan PLPG dalam meningkatkan kompetensi profesional. Tujuan penelitian ini adalah untuk mengetahui pengaruh PLPG dalam meningkatkan kompetensi guru jenis penelitian yang di gunakan adalah penelitian kuantitatif dengan teknik pengumpulan data menggunakan cara observasi, dokumentasi dan angket. Teknik analisis data menggukan teknik analisis data kuantitatif. Hasil penelitian menunjukkan bahwa pelatihan PLPG memberi pengaruh terhadap kompetensi guru, hal ini dilihat dari nilai signifikansi 0,001 dengan nilai uji-t adalah 1,196. Berdasarkan kriteria yang telah ditetapkan jika signifikansi adalah $0,001<0,005$ maka $\mathrm{H}_{0}$ ditolak itu berarti tidak ada pengaruh PLPG dengan kompetensi guru sementara H11 diterimah menunjukkan bahwa pelatihan PLPG mempunyai pengaruh terhadap kompetensi profesional guru
\end{abstract}

Kata kunci: Pelatihan, PLPG, Kompetensi Guru 


\section{INTRODUCTION}

Education is an essential thing in our lives, which means that every human being has the right to get an education. Education, in general, has the meaning of a life process in developing each individual to be able to live and carry out life. This is in line with the contents of the Preamble to the 1945 Constitution of the Republic of Indonesia, Paragraph IV, which states that one of the goals of the Indonesian nation is "Educating the Life of the Nation". Education can be obtained from the family and community environments, but the most urgent is education in the school environment.

Education to realize this requires quality human resources, in this case, the teacher is one of the most important components of education to be considered by the government because the teacher has a large and strategic role in improving the quality of education because it is the teacher who deals directly with students to improve the quality of education. Transferring knowledge and technology and educating with positive values through guidance and example without forgetting the other components, including educational goals, students, curriculum, educational environment and educative interactions, and teaching tools. The definition of teacher in Law Number 14 of 2005 in Article 1 paragraph (1) Regarding Teachers and Lecturers are professional educators with the main task of educating, teaching, guiding, directing, training, assessing and evaluating students in early childhood education through the educational pathway. formal education, primary education and secondary education.

In the Government Regulation of the Republic of Indonesia Number 32 of 2013 concerning National Education Standards, improving the quality and competitiveness of Indonesian human resources as a result of education has become a national commitment "stating that one of the core substances of the education sector action program is the restructuring of the school curriculum so that it can encourage the creation of results. Students who can answer the needs of human resources to support national and regional growth. Thus, the consolidation of National Education Standards and curriculum arrangements as a whole is essential and urgent to achieve these goals.

Law no. 14 of 2013 concerning Teachers and Lecturers defines that professionals are work or activities carried out by a person and become a source of income for life that requires expertise, proficiency or skills that meet certain quality standards or norms and need professional education. In other words, professional teachers are trained, educated and responsible and have experience in the world of education.

An educator certificate evidences the position of the teacher as a professional. Therefore, teachers are expected to carry out activities to improve their competence and 
professionalism. The demands of teacher professionalism must be addressed by increasing qualifications and competencies, especially now that there is a need to take a certification test to determine one's eligibility.

In Permendikbud Number 19 of 2017 Article 1 paragraphs 3 and 4 state that paragraph: (3) certification is the process of granting teacher educator certificates. (4) educator certificate is formal evidence as an acknowledgement of teachers as professionals.

The primary purpose of teacher professional education and training (PLPG) is to obtain certification. In addition, teacher professional education and training (PLPG) also increases the dignity of a teacher and the role of the teacher as a learning agent. (PLPG) is considered a professional educator who can educate well to improve the quality of education in a sustainable manner. In accordance with the Law of the Republic of Indonesia No. 20 of 2003 concerning the National Education System, it is stated that education providers and training institutions give competency certification to students and community members. As an acknowledgment of the competence to do certain jobs after passing the competency test held by an accredited educational unit or certification body.

However, in reality, in the field, teachers are often found not to have the professional competencies that should be possessed to carry out their duties and responsibilities in education, so that usually the objectives of learning are not achieved because of the ineffectiveness of teachers teaching in the classroom. This makes it challenging to improve the quality of education.

SMA Negeri 2 Bantaeng is one of the schools in Bantaeng that has teachers who have passed the education and professional training of teachers (PLPG), for that it is expected that teachers who have passed the education and professional training of teachers (PLPG) in the school can have professional competence.

Starting from stated above, the authors are interested in researching "The Effect of Educational Training and Teacher Professional Training (PLPG) in Improving Teacher Professional Competence at SMA Negeri 2 Bantaeng".

\section{RESEARCH METHODS}

In this study, the type of research used was quantitative research. Quantitative research methods were one type of research whose specifications are systematic, wellplanned, and clearly structured from the beginning to the making of the research design. According to (Sugiyono 2012) quantitative research methods were interpreted as research methods based on the philosophy of positivism, used to examine certain populations or samples. Another definition states that quantitative research was research that demands the use of numbers, starting from 
data collection and the appearance of the results.

The research location was the place where a researcher conducted research or the place where the research was carried out. This research was conducted at SMA Negeri 2 Bantaeng in Bantaeng Regency. The research was carried out from August to September in the 2018-2019 school year. Primary data was data obtained directly from the source, observed, and recorded.

The primary data obtained were data on educational training and teacher professional training (PLPG) in improving the competence of teachers at SMA Negeri 2 Bantaeng in Bantaeng Regency through Questionnaires and Observations. Secondary data in this study was data obtained not directly from the source. In this study, the secondary data sources used were written sources such as sources of books, scientific magazines and documents from related parties regarding the role of teacher professional education and training (PLPG) in improving teacher competence, with the number of teachers who had professional education and training. Teachers (PLPG) 19 people and before education and professional training for teachers (PLPG) 20 people.

The population in this study was all students in SMA Negeri 2 Bantaeng, with 881 people. The sample was part of the population. In this study, the sample was 29 students at SMA Negeri 2 Bantaeng. Determination of the sample using the purposive sampling technique, where data collection was selected with certain considerations.

A research instrument was a tool that was used in digging up data in this study. The data is excavated with the instrument, namely the researcher himself, who directly witnesses the phenomena related to the object under investigation utilizing observation instruments, questionnaires and document studies.

The data collection technique in this research is the technique of observation, documentation and questionnaires. Observations were made to see firsthand how professional teachers are in teaching. The documentation method is a way of collecting data related to the effect of educational training and teacher professional training (PLPG) in improving teacher competence. A questionnaire was a data collection technique by asking the respondents written questions in writing.

Analysis of the data used in this study was the statistical analysis of the t-test. The formula used to calculate the percentage of the questionnaire results is as follows:

$\mathrm{P}=\frac{f}{n} \times 100$

Where :

$\mathrm{P}$ : The percentage of the answer

F : Frequency of Respondents' Answers

$\mathrm{n}$ : Number of Respondents 


\section{DISCUSSION}

To interpret the results of the questionnaire, researchers are guided by the following data:

\begin{tabular}{|c|c|}
\hline $0 \%$ & No one \\
\hline $1 \%-5 \%$ & Almost no \\
\hline $6 \%-25 \%$ & a bit small \\
\hline $26 \%-49 \%$ & Almost half \\
\hline $50 \%$ & half \\
\hline $51 \%-75 \%$ & More than half \\
\hline $76 \%-95 \%$ & most of the \\
\hline $96 \%-99 \%$ & almost completely \\
\hline $100 \%$ & all \\
\hline
\end{tabular}

Source: (Kusmiati, 2004)

Discussion of the results of the questionnaire based on the sequence of statements as follows:

\section{Before Doing PLPG}

1. Opening Lessons

\begin{tabular}{|c|c|c|}
\hline $\begin{array}{c}\text { Answer } \\
\text { Choices }\end{array}$ & $\begin{array}{c}\text { Total } \\
\text { Answers }\end{array}$ & Percentage \\
\hline Yes & 25 & $86,20 \%$ \\
No & 4 & 13,79 \\
\hline Total & 29 & $100 \%$ \\
\hline
\end{tabular}

Based on the questionnaire results contained in the table, it is known that the number of respondents was 29 people. Respondents who answered "Yes" to the first statement were 25 people with a percentage of $86.20 \%$, and the answer "No" was four people with a percentage of $13.79 \%$. So it can be concluded that most of the respondents answered yes that teachers who have not conducted teacher professional education and training (PLPG) open lessons.
2. Motivating Students

\begin{tabular}{|c|c|c|}
\hline $\begin{array}{c}\text { Answer } \\
\text { Choices }\end{array}$ & $\begin{array}{c}\text { Total } \\
\text { Answers }\end{array}$ & Percentage \\
\hline Yes & 17 & $58,62 \%$ \\
No & 12 & $41,37 \%$ \\
\hline Total & 29 & $100 \%$ \\
\hline
\end{tabular}

Based on the questionnaire results contained in the table, it is known that the number of respondents was 29 people. Respondents who answered "Yes" to the first statement were 17 people with a percentage of $58.62 \%$, and the answer "No" was 12 people with $41.37 \%$. More than half of the respondents answered yes, so it can be concluded that teachers who have not carried out professional education and training (PLPG) in motivating students.

3. Giving Feedback

\begin{tabular}{|c|c|c|}
\hline $\begin{array}{c}\text { Answer } \\
\text { Choices }\end{array}$ & $\begin{array}{c}\text { Total } \\
\text { Answers }\end{array}$ & Percentage \\
\hline Yes & 21 & $72,41 \%$ \\
No & 8 & $27,58 \%$ \\
\hline Total & 29 & $100 \%$ \\
\hline
\end{tabular}

Based on the questionnaire results contained in the table, it is known that the number of respondents was 29 people. Respondents who answered "Yes" to the first statement were 21 people with a percentage of $72.41 \%$, and the answer "No" was eight people with a percentage of $27.58 \%$. More than half of the respondents answered yes, so it can be concluded that teachers who have not carried out teacher professional education and training (PLPG) in providing feedback. 
4. Mastery of Study Materials

\begin{tabular}{|c|c|c|}
\hline $\begin{array}{c}\text { Answer } \\
\text { Choices }\end{array}$ & Total Answers & Percentage \\
\hline Yes & 21 & $72,41 \%$ \\
No & 8 & $27,58 \%$ \\
\hline Total & 29 & $100 \%$ \\
\hline
\end{tabular}

Based on the questionnaire results contained in the table, it is known that the number of respondents was 29 people. Respondents who answered "Yes" to the first statement were 21 people with a percentage of $72.41 \%$, and the answer "No" was eight people with a percentage of $27.58 \%$. So it can be concluded that teachers who have not conducted teacher professional education and training (PLPG) in mastering the field of study, more than half of the respondents answered yes.

\begin{tabular}{|c|c|c|}
\hline $\begin{array}{c}\text { Answer } \\
\text { Choices }\end{array}$ & $\begin{array}{c}\text { Total } \\
\text { Answers }\end{array}$ & Percentage \\
\hline Yes & 28 & $72,41 \%$ \\
No & 1 & $27,58 \%$ \\
\hline Total & 29 & $100 \%$ \\
\hline
\end{tabular}

Based on the questionnaire results contained in the table, it is known that the number of respondents was 29 people. Respondents who answered "Yes" to the first statement were 21 people with a percentage of $72.41 \%$, and the answer "No" was 8 people with a percentage of $27.58 \%$. So it can be concluded that teachers who have not carried out professional education and training (PLPG) in managing teaching and learning programs, more than half of the respondents answered yes.
5. Teaching and Learning Program Management

\begin{tabular}{|c|c|c|}
\hline $\begin{array}{c}\text { Answer } \\
\text { Choices }\end{array}$ & $\begin{array}{c}\text { Total } \\
\text { Answers }\end{array}$ & Percentage \\
\hline Yes & 28 & $72,41 \%$ \\
No & 1 & $27,58 \%$ \\
\hline Total & 29 & $100 \%$ \\
\hline
\end{tabular}

Based on the questionnaire results contained in the table, it is known that the number of respondents was 29 people. Respondents who answered "Yes" to the first statement were 21 people with a percentage of $72.41 \%$, and the answer "No" was eight people with a percentage of $27.58 \%$. So it can be concluded that teachers who have not carried out professional education and training (PLPG) in managing teaching and learning programs, more than half of the respondents answered yes.

6. Class Management

\begin{tabular}{|l|l|l|}
\hline $\begin{array}{l}\text { Answer } \\
\text { Choices }\end{array}$ & $\begin{array}{l}\text { Total } \\
\text { Answers }\end{array}$ & Percentage \\
\hline Yes & 22 & $75,86 \%$ \\
No & 7 & $24,13 \%$ \\
\hline Total & 29 & $100 \%$ \\
\hline
\end{tabular}

Based on the questionnaire results contained in the table, it is known that the number of respondents was 29 people. Respondents who answered "Yes" to the first statement were 22 people with a percentage of $75.86 \%$, and the answer "No" was seven people with $24.13 \%$. So it can be concluded that more than half of the respondents who have not carried out teacher professional education and training (PLPG) in managing classes answered yes. 
7. Using Learning Media

\begin{tabular}{|c|c|c|}
\hline $\begin{array}{c}\text { Answer } \\
\text { Choices }\end{array}$ & $\begin{array}{c}\text { Total } \\
\text { Answers }\end{array}$ & Percentage \\
\hline Yes & 21 & $72,41 \%$ \\
No & 8 & $27,58 \%$ \\
\hline Total & 29 & $100 \%$ \\
\hline
\end{tabular}

Based on the results of the questionnaire contained in the table, it is known that the number of respondents was 29 people. Respondents who answered "Yes" to the first statement were 21 people with a percentage of $72.41 \%$, and the answer "No" was eight people with a percentage of $27.58 \%$. More than half of the respondents answered yes so it can be concluded that teachers who have not carried out professional education and training (PLPG) in using learning media.

8. Mastery of Educational Foundation

\begin{tabular}{|c|c|c|}
\hline $\begin{array}{c}\text { Answer } \\
\text { Choices }\end{array}$ & $\begin{array}{c}\text { Total } \\
\text { Answers }\end{array}$ & Percentage \\
\hline Yes & 24 & $82,75 \%$ \\
No & 5 & $17,24 \%$ \\
\hline Total & 29 & $100 \%$ \\
\hline
\end{tabular}

Based on the questionnaire results contained in the table, it is known that the number of respondents was 29 people. Respondents who answered "Yes" to the first statement were 24 people with a percentage of $82.75 \%$, and the answer "No" was five people with a percentage of $17.24 \%$. More than half of the respondents answered yes, so it can be concluded that teachers who have not completed professional education and training (PLPG) in mastering the educational foundation.
9. Able to Assess Learning Achievement.

\begin{tabular}{|c|c|c|}
\hline $\begin{array}{c}\text { Answer } \\
\text { Choices }\end{array}$ & $\begin{array}{c}\text { Total } \\
\text { Answers }\end{array}$ & Percentage \\
\hline Yes & 21 & $72,41 \%$ \\
No & 8 & $27,58 \%$ \\
\hline Total & 29 & $100 \%$ \\
\hline
\end{tabular}

Based on the questionnaire results contained in the table, it is known that the number of respondents was 29 people. Respondents who answered "Yes" to the first statement were 21 people with a percentage of $72.41 \%$, and the answer "No" was eight people with a percentage of $27.58 \%$. More than half of the respondents answered yes, so it can be concluded that teachers who have not carried out professional education and training (PLPG) in assessing learning achievement.

Based on the questionnaire results contained in the table, it is known that the number of respondents was 29 people. Respondents who answered "Yes" to the first statement were 27 people with a percentage of $93.10 \%$, and the answer "No" was two people with a percentage of $6.89 \%$. More than half of the respondents answered yes, so it can be concluded that teachers who have not carried out professional education and training (PLPG) understand the principles of managing educational institutions and programs.

10. Understand the Principles of Management of Educational Institutions and Programs.

\begin{tabular}{|c|c|c|}
\hline $\begin{array}{c}\text { Answer } \\
\text { Choices }\end{array}$ & $\begin{array}{c}\text { Total } \\
\text { Answers }\end{array}$ & Percentage \\
\hline Yes & 25 & $86,20 \%$ \\
No & 4 & $13,79 \%$ \\
\hline Total & 29 & $100 \%$ \\
\hline
\end{tabular}


Based on the questionnaire results contained in the table, it is known that the number of respondents was 29 people. Respondents who answered "Yes" to the first statement were 25 people with a percentage of $86.20 \%$, and the answer "No" was four people with a percentage of $13.79 \%$. So it can be concluded that most of the respondents answered yes to teachers who have conducted professional education and training (PLPG) in understanding the principles of managing educational institutions and programs.

11. Mastering the Thinking Method

\begin{tabular}{|c|c|c|}
\hline $\begin{array}{c}\text { Answer } \\
\text { Choices }\end{array}$ & $\begin{array}{c}\text { Total } \\
\text { Answers }\end{array}$ & Percentage \\
\hline Yes & 21 & $72,41 \%$ \\
No & 8 & $27,58 \%$ \\
\hline Total & 29 & $100 \%$ \\
\hline
\end{tabular}

Based on the questionnaire results contained in the table, it is known that the number of respondents was 29 people. Respondents who answered "Yes" to the first statement were 21 people with a percentage of $72.41 \%$, and the answer "No" was eight people with a percentage of $27.58 \%$. So it can be concluded that more than half of the respondents answered yes for teachers who have conducted teacher professional education and training (PLPG) in understanding thinking methods.

12. Improving Skills and Carrying Out Professional Missions

\begin{tabular}{|c|c|c|}
\hline $\begin{array}{c}\text { Answer } \\
\text { Choices }\end{array}$ & $\begin{array}{c}\text { Total } \\
\text { Answers }\end{array}$ & Percentage \\
\hline Yes & 27 & $93,10 \%$ \\
No & 2 & $6,89 \%$ \\
\hline Total & 29 & $100 \%$ \\
\hline
\end{tabular}

Based on the questionnaire results contained in the table, it is known that the number of respondents was 29 people. Respondents who answered "Yes" to the first statement were 27 people with a percentage of 93.10\%, and the answer "No" was two people with a percentage of $6.89 \%$. So it can be concluded that most of the respondents answered yes to teachers who have carried out teacher professional education and training (PLPG) in assessing learning achievement.

13. Skilled in Providing Assistance and Guidance to Students

\begin{tabular}{|c|c|c|}
\hline $\begin{array}{c}\text { Answer } \\
\text { Choices }\end{array}$ & $\begin{array}{c}\text { Total } \\
\text { Answers }\end{array}$ & Percentage \\
\hline Yes & 26 & $89,65 \%$ \\
No & 3 & $10,34 \%$ \\
\hline Total & 29 & $100 \%$ \\
\hline
\end{tabular}

Based on the questionnaire results contained in the table, it is known that the number of respondents was 29 people. Respondents who answered "Yes" to the first statement were 26 people with a percentage of $89.65 \%$, and three people answered "No" with a percentage of $10.34 \%$. So it can be concluded that most of the respondents answered yes to teachers who have carried out professional teacher education and training (PLPG) in providing assistance and guidance to students.

14. Have Insights About Research

\begin{tabular}{|c|c|c|}
\hline $\begin{array}{c}\text { Answer } \\
\text { Choices }\end{array}$ & $\begin{array}{c}\text { Total } \\
\text { Answers }\end{array}$ & Percentage \\
\hline Yes & 14 & $48,27 \%$ \\
No & 15 & $51,72 \%$ \\
\hline Total & 29 & $100 \%$ \\
\hline
\end{tabular}


Based on the questionnaire results contained in the table, it is known that the number of respondents was 29 people. Respondents who answered "Yes" to the first statement were 14 people with a percentage of $48.27 \%$, and the answer "No" was 15 people with a percentage of $51.72 \%$. So it can be concluded that teachers who have conducted teacher professional education and training (PLPG) in research insight more than half of the respondents answered no.

15. Getting to Know the Characters of Students

\begin{tabular}{|c|c|c|}
\hline $\begin{array}{c}\text { Answer } \\
\text { Choices }\end{array}$ & $\begin{array}{c}\text { Total } \\
\text { Answers }\end{array}$ & Percentage \\
\hline Yes & 17 & $58,62 \%$ \\
No & 12 & $41,37 \%$ \\
\hline Total & 29 & $100 \%$ \\
\hline
\end{tabular}

Based on the questionnaire results contained in the table, it is known that the number of respondents was 29 people. Respondents who answered "Yes" to the first statement were 17 people with a percentage of $58.62 \%$, and the answer "No" was 12 people with $41.37 \%$. So it can be concluded that teachers who have conducted teacher professional education and training (PLPG) in recognizing students' character, more than half of the respondents answered yes.

16. Using Time Correctly

\begin{tabular}{|c|c|c|}
\hline $\begin{array}{c}\text { Answer } \\
\text { Choices }\end{array}$ & $\begin{array}{c}\text { Total } \\
\text { Answers }\end{array}$ & Percentage \\
\hline Yes & 18 & $62,06 \%$ \\
No & 11 & $37,93 \%$ \\
\hline Total & 29 & $100 \%$ \\
\hline
\end{tabular}

Based on the questionnaire results contained in the table, it is known that the number of respondents was 29 people. Respondents who answered "Yes" to the first statement were 18 people with a percentage of $62.06 \%$, and the answer "No" was 11 people with a percentage of $37.93 \%$. More than half of the respondents answered yes, so it can be concluded that teachers who have carried out teacher professional education and training (PLPG) in using time appropriately.

17. Concluding the Lesson

\begin{tabular}{|c|c|c|}
\hline $\begin{array}{c}\text { Answer } \\
\text { Choices }\end{array}$ & $\begin{array}{c}\text { Total } \\
\text { Answers }\end{array}$ & Percentage \\
\hline Yes & 21 & $72,41 \%$ \\
No & 8 & $27,58 \%$ \\
\hline Total & 29 & $100 \%$ \\
\hline
\end{tabular}

Based on the questionnaire results contained in the table, it is known that the number of respondents was 29 people. Respondents who answered "Yes" to the first statement were 21 people with a percentage of $72.41 \%$, and the answer "No" was eight people with a percentage of $27.58 \%$. So it can be concluded that more than half of the respondents who have conducted teacher professional education and training (PLPG) in concluding lessons answered yes.

\section{Test Data Analysis}

a. Normality test

\begin{tabular}{|l|c|c|}
\hline & $\mathrm{X}$ & $\mathrm{Y}$ \\
\hline $\mathrm{N}$ & 29 & 29 \\
Normal & 62,3333 & 86,7619 \\
Parameters $^{\mathrm{a}, \mathrm{b}}$ & 10,60346 & 5,83871 \\
Mean &, 254 &, 184 \\
Std.Deviation &, 254 &, 142 \\
&,- 152 &,- 187 \\
\hline
\end{tabular}




\begin{tabular}{|l|c|c|}
\hline Most Extreme & 1,163 &, 855 \\
Differences &, 134 &, 458 \\
Absolute & & \\
$\quad$ Positive & & \\
$\quad$ Negative & & \\
Kolmogorov- & & \\
Smirnov Z & & \\
Asymp. Sig. (2- & & \\
tailed) & & \\
\hline
\end{tabular}

Tabel . One-Sample Kolmogorov-Smirnov

\begin{tabular}{|c|c|c|c|c|c|c|}
\hline \multirow{2}{*}{\multicolumn{2}{|c|}{$\begin{array}{c}\text { Teacher } \\
\text { Competance }\end{array}$}} & \multicolumn{2}{|c|}{$\begin{array}{l}\text { Levene's } \\
\text { Test for } \\
\text { Equality } \\
\text { of } \\
\text { Variances }\end{array}$} & \multicolumn{3}{|c|}{$\begin{array}{l}\text { t-test for } \\
\text { Equality of } \\
\text { Means }\end{array}$} \\
\hline & & $\mathrm{F}$ & $\begin{array}{c}\text { Sig } \\
\text {. }\end{array}$ & $\mathrm{T}$ & $\mathrm{Df}$ & $\begin{array}{l}\text { Sig. } \\
(2- \\
\text { tailed } \\
\quad)\end{array}$ \\
\hline $\begin{array}{l}\text { Sk } \\
\text { or }\end{array}$ & $\begin{array}{l}\text { Equal } \\
\text { Varia } \\
\text { nces } \\
\text { assum } \\
\text { ed } \\
\text { Equal } \\
\text { Varia } \\
\text { nces } \\
\text { not } \\
\text { assum } \\
\text { ed }\end{array}$ & $\begin{array}{l}1,19 \\
6\end{array}$ & $\begin{array}{l}, 86 \\
7\end{array}$ & $\begin{array}{l}3 \\
5 \\
0 \\
\end{array}$ & $\begin{array}{l}40 \\
39 \\
, 4 \\
6\end{array}$ & $\begin{array}{l}, 002 \\
, 002\end{array}$ \\
\hline
\end{tabular}

Note:
a. Test Distribution is Normal
b. Calculated from data

Test criteria: If Sign. $>0.05$ Then the data is "Normal" If Sign. $<0.05$ Then the data "Not Normal" From the results of the normality test $\mathrm{X}=0.134$ and $\mathrm{Y}=0.458$, both data are greater than 0.05 , so it can be concluded that the data has a "Normal" distribution. c. Homogeneity Test

\begin{tabular}{|l|l|l|l|}
\hline \multicolumn{2}{|c|}{} & \multicolumn{2}{|l|}{$\begin{array}{l}\text { Levene's Test for } \\
\text { Equality of } \\
\text { Variances }\end{array}$} \\
\cline { 3 - 4 } & F & Sig. \\
\hline $\begin{array}{l}\text { Scor } \\
\text { e }\end{array}$ & $\begin{array}{l}\text { Equal } \\
\text { Variances } \\
\text { assumed } \\
\text { Equal } \\
\text { Variances not } \\
\text { Vassumed }\end{array}$ & 1,196 &, 867 \\
\hline
\end{tabular}

The homogeneity test results at a significance level of $=0.05$ indicate homogeneous data. This can be obtained by comparing the significance value listed in the homogeneity test results table, where the significance is 0.867 , which states that it is greater than the alpha value $(\alpha)$, which is 0.05 c. Hypothesis testing

Based on the data analysis test results, it can be seen that they have the same variance. This shows that the group is homogeneous so that hypothesis testing can be carried out.The results From the homogeneity data test results show that the value of sig. $=0.867$ is on the Equal Variances Assumed line, then the significance of the t-test is read on that line 1 side of the significance value must be divided by 2 , so the significance value is 0.001 with the $\mathrm{t}$-test value is 1.196 . Based on the criteria that have been set, if the significance is $0.001<$ 0.005 , then $\mathrm{H} 0$ is rejected, it means that there is no effect of Teacher Professional Education and Training with teacher competence while H11 is accepted, indicating that Teacher Professional Education and Training training 
influences the professional competence of teachers at SMA Negeri 2 Bantaeng

Teacher Professional Education and Training is an activity carried out to increase professional competence, strengthen teacher mastery and ability in implementing the 2013 curriculum, and determine teacher graduation as certification participants.

In this study, researchers tried to see the effect of teacher training and professional training on the professional competence of teachers. This can be seen in the learning process and also in distributing questionnaires. The questionnaire results for teachers who have not conducted Teacher Professional Education and Training training are 365 with an average of 12.58 , while the questionnaire obtained for teachers who have conducted Teacher Professional Education and Training training is 393 with an average of 13.55 . The questionnaire This is distributed among 29 students.

The results of this study are supported by previous research conducted by Irnawati in the title of the thesis, "The Contribution of Education and Education and Teacher Professional Training (PLPG) in improving the competence of PPKn teachers" PPKn study program, Faculty of Social Sciences, Makassar State University. With research showing that there is an influence of the contribution of education and education and professional teacher training (PLPG) in improving teacher competence, as well as the results of research conducted by Aprian Syarif Hidayat with the thesis title "The Influence of Education and Education and Teacher Professional Training (PLPG) in Supporting Professionalism Social science teacher (IPS)" Social Science Education Study Program, Faculty of Tarbiyah and Teacher Training, Jakarta State Islamic University.

Based on the results obtained in research conducted at SMA Negeri 2 Bantaeng regarding the effect of Teacher Professional Education and Training training on teacher professional competence when compared to teachers who have not conducted Teacher Professional Education and Training training and teachers who have conducted Teacher Professional Education and Training training have differences in the professional competence of teachers as expected by researchers with optimal results.

This can be seen in the criteria that have been set, if the significance is $0.001<0.005$, then $\mathrm{HO}$ is rejected, it means that there is no effect of Teacher Professional Education and Training with teacher competence while H11 is accepted, indicating that Teacher Professional Education and Training training influences the professional competence of teachers in SMA Country 2 Bantaeng.

\section{CONCLUSION}

Teacher Education and Professional Training training affect teacher competence. This can be seen from the significance gain is 
0.001 with a t-test value of 1.196 . Based on the established criteria, if the significance is 0.001 $<0.005$, then $\mathrm{H} 0$ is rejected, it means that there is no influence of teacher professional education and training (PLPG) with teacher competence. At the same time, $\mathrm{H} 11$ is accepted, indicating that teacher professional education and training (PLPG) influences teacher professional competence.

\section{REFERENCES}

[1] Afrian syarif Hidayat. (2018). Pengaruh Pendidikan Dan Latihan Profesi Guru (PLPG) dalam Menunjang Profesionalisme Guru IPS.

[2] Azmuyardi, Azra,, (2008). Pendidikan Kewarganegaraan, Demokrasi, Hak Asasi Manusia dan Masyarakat Madani, Kencana, Jakarta.

[3] Branson, (1999). Belajar Civic Education dari Amerika.. Yogyakarta: lkis

[4] Cholisin, (2000). Materi Pokok Ilmu Kewarganegaraan-Pendidikan Kewarganegaraan. Yogyakarta.

[5] Moleong, (2007). Metodologi Penelitian Kualitatif. Bandung: Remaja Karya.

[6] Rastodio, (2009), Kompetensi Guru, Jakarta; Bumi Aksara, Jaya Negara

[7] Ruminiati, (2007). Pengembangan Pendidikan Kewarganegaraan. Jakarta: Direktorat Jenderal Pendidikan Tinggi Departemen Pendidkan Nasional.

[8] Sevilla, dkk, (1993). Pengantar Metode Penelitian. Jakarta: UI Pres.

[9] Soemantri, (2001). Fungsi Pendidikan Kewarganegaraan. Jakarta.

[10] Sugiyono. (2013). Metode Penelitian Pendidikan Pendekatan Kuantitatif Kualitatif dan $R \& D$. Bandung: Alfabeta.
[11] Yudi Bakti. (2018). Kontribusi Pendidikan dan Pelatihan Profesi Guru dalam meningkatkan profesional guru PPKn. 2010/2011 Daerah Istimewa Yogyakarta.

[12] Zamroni, (2001). Pendidikan Untuk Demokrasi. Bilgraf Publising, Yogyakarta.

[13] Undang-Undang No. 2 Tahun (1989) tentang sistem Pendidikan Nasional

[14] Undang-Undang Nomor 20 Pasal 1 ayat 2 Tahun 2003 Tentang sistem Pendidikan Nasional.

[15] Undang-Undang Nomor 14 Pasal 1 Ayat (1) Tahun 2005 Tentang Guru dan Dosen.

[16] Undang-Undang Nomor 14 Pasal 11 Tahun 2005 Tentang Guru dan Dosen.

[17] Undang-Undang Nomor 14 Tahun 2013 Tentang Guru dan Dosen

[18] Undang-Undang Nomor 18 Pasal 2 Ayat (5) Tahun 2007 Tentang Sertifikasi Guru dan Jabatan.

[19] Undang-Undang Republik Indonesia Nomor 20 Tahun 2003 Tentang Sistem Pendidikan Nasional.

[20] Peraturan Pemerintah Nomor 19 Pasal 28 Ayat (3) Tahun 2005 Tentang Standar Nasional Pendidikan.

[21] Undang-Undang Nomor 20 Tahun 2003 Tentang Sistem Pendidikan Nasional.

[22] Undang-Undang Nomor 22 Pasal 39 Tahun 1999 tentang Sistem Pendidikan Nasional

[23] Permendiknas No. 22 Tahun 2006 tentang standar Isi Pendidikan Nasional.

[24] Permendikbud No. 16 Tahun 2007 Tentang Standar Kualifikasi Akademik dan Kompetensi Guru.

[25] Permendikbud Nomor . 21,22 dan 23 Tahun 2016 tentang Standar Kompetensi Kelulusan.

[26] Permendikbud Nomor 22 Pasal 1 Tahun 2016 tentang Standar Proses Pendidikan Dasar dan Menengah

[27] Permendikbud Nomor 19 Pasal 1 ayat 3 dan 4 Tahun 2017 tentang sertifikat pendidik. 
DOI: $10.26618 /$ jed.v7i1.6812

Vol: 7 Number 1, January 2022

Page: 195-207

[28] Permendikbud Nomor 29 Tahun 2016 tentang Serifikasi Guru.

[29] Permendikbud Nomor 37 Tahun 2017 tentang Serifikasi Guru dalam Jabatan.

[30] Permendikbud Pasal 1 ayat 2 Nomor 16 Tahun 2018 tentang penugasan guru sebagai kepala sekolah. 